\section{'Jinyan', an Interspecific Hybrid Kiwifruit with Brilliant Yellow Flesh and Good Storage Quality}

Caihong Zhong, Shengmei Wang, and Zhengwang Jiang Key Laboratory of Plant Germplasm Enhancement and Speciality Agriculture and Wuhan Botanical Garden, Chinese Academy of Sciences, Wuhan, Hubei 430074, P.R. China

\section{Hongwen Huang ${ }^{1}$ \\ Key Laboratory of Plant Resources Conservation and Sustainable Utilization, South China Botanical Garden, Chinese Academy of Sciences, Guangzhou, Guangdong 510650, China}

Additional index words. new cultivar, hybridization, Actinidia eriantha, Actinidia chinensis var. chinensis

In the world kiwifruit industry, there are both green-fleshed and yellow-fleshed kiwifruit in the marketplace (Huang, 2009). The dominant position of the green-fleshed kiwifruit is changing. The green-fleshed kiwifruit, represented by 'Hayward', dominate the international kiwifruit market because of good marketability and outstanding storage quality. However, during the past two decades, yellow-fleshed kiwifruit such as 'Hort16A' in New Zealand and 'Jintao' in China have also been developed. These new yellow-fleshed cultivars are sweeter and more aromatic than 'Hayward' and have attracted much attention from consumers. The purchase price for 'Hort 16A' or 'Jintao' is at least 30\% higher than that for 'Hayward'. However, in general, the storage life of yellow-fleshed cultivars is not as good as that of 'Hayward'. This limited storage life has resulted in considerable fresh fruit losses. Therefore, it is necessary to breed new yellow-fleshed cultivars with long storage and shelf life.

Hybridization, especially interspecific hybridization, is a very important method to develop new kiwifruit cultivars, which can combine the good traits from different species in the genus Actinidia. The hybrid can be intermediate types or types with combinations of the dominant traits of its parents or can even obtain new traits and variation, which the parents do not possess. For example, 'Kiri', a selection developed from the hybridization between $A$. arguta (Sieb. \& Zucc.) Planch. ex Miq. and $A$. chinensis Planch. var. deliciosa Cheval, and backcrossing to $A$. chinensis var.

Received for publication 17 Nov. 2011. Accepted for publication 11 June 2012.

We thank Xu Liyun, Han Fei, and Liu Xiaoli for collecting phenology data and Li Dawei and Zhang Peng for collecting harvest and storage data. We also thank Professor Ross Ferguson, Dr. Xiaohong Yao, and Yifei Liu for their assistance in preparation of the manuscript.

${ }^{1}$ To whom reprint requests should be addressed; e-mail huanghw@mail.scbg.ac.cn. deliciosa, had large fruit averaging $100 \mathrm{~g}$ with smooth and edible fruit skin, resulting in a successful combination of the good traits of A. arguta and $A$. chinensis var. deliciosa (White and Beatson, 1993). However, its fruit skin was easily damaged and its storage life was short. Unfortunately, up to now, there have been no kiwifruit cultivars arising from interspecific hybridization that are cultivated widely or are important in the kiwifruit industry.

'Jinyan', a new yellow-fleshed, late-season kiwifruit cultivar with large fruit size, good taste, and excellent storage quality and shelf life (Fig. 1), was developed by the Wuhan Botanical Garden, Chinese Academy of Sciences (Wang et al., 1989, 1994, 2000). 'Jinyan' is the first good kiwifruit cultivar originating from interspecific hybridization in China. This article describes its origin, the cultivar characteristics, and commercialization.

\section{Origin}

In 1984, the cross was conducted with Actinidia eriantha Benth. as the female parent and $A$. chinensis var. chinensis Planch. as the male parent. The female plant of $A$. eriantha was a selection with large fruit size originated from its natural distribution in Fujian Province, whereas pollens were used from several male plants of $A$. chinensis var. chinensis originally collected from its natural range in Jiangxi Province. In 1985, the hybrid seeds were sown after stratification in a greenhouse. From 1987 to 1989 , a total of $69 \mathrm{~F}_{1}$ seedlings were obtained after an initial screening for desirable traits. These hybrid plants have a wide spectrum of flower colors ranging from white color similar to the male parent to various red colors similar to the female parent. Only seven female plants with white flowers produced fruit normally and a superior plant whose fruit stored best was selected and labeled as $\mathrm{M}_{3}$. The $\mathrm{M}_{3}$ produced fruit with shape, hairness, skin, and flesh color similar to the male parent and flesh texture and maturity similar to those of its female parent. Five mitochondrial DNA markers (atp, nad2-31-1, nad24F, nad24R, and $r p s$ ) were used to test its hybrid origin, revealing a complete sequence consistency of all mitochondrial DNA markers between $\mathrm{M}_{3}$ and its female parent, A. eriantha (data not shown).

From 1990 to 1996 , many clonal plants propagated from the $M_{3}$ were evaluated for genetic stability of biology characteristics by top-grafting. During1996 to 2006, the adaptability of $\mathrm{M}_{3}$ plants to different ecological environments was tested in Hubei, Jiangxi, Yunnan, Sichuan, and Shaanxi Provinces. The results indicated that the $\mathrm{M}_{3}$ was stable in genetic traits, including outstanding storage life, and other excellent fruit traits. $\mathrm{M}_{3}$ was authorized by Hubei Provincial Forest Cultivar Appraisal Committee in 2006 and named 'Jinyan' (cultivar No. E.S-SC-AC-002-2006). The application made to the Ministry of Agriculture, China, for cultivar protection was approved in 2009 (Variety Right Number CNA20070118.5). In 2010, 'Jinyan' was also authorized as a new kiwifruit cultivar in China by the National Forestry Cultivar Approval Committee (national cultivar No. S-SV-AE019-2010).

The propagation and production of 'Jinyan' was licensed domestically to China New Agricultural Science \& Technology Co. Ltd (Sichuan, China) in 2007. This company has established kiwifruit orchards of 700 ha in Chengdu, Sichuan Province, and also subcontracted many kiwifruit growers in main kiwifruit production areas of Sichuan and Shaanxi Provinces. 'Jinyan' is now widely commercialized for kiwifruit production in China.

\section{Description}

'Jinyan' is tetraploid with strong vine vigor. One-year-old shoots are dark brown and 2-year-old shoots are reddish brown. Internodes are 5 to $15 \mathrm{~cm}$ long. Lenticels are elliptical and brown. The leaf blade is large, round, and chartaceous $(19 \mathrm{~cm} \times 15 \mathrm{~cm}$ long and wide, respectively). The leaf margin has serrulations, leaf basal lobes are slightly apart, and the leaf apex is round. The leaf upper surface is hairless and dark green, but the lower surface is densely covered with greenish hairs. The petiole is 4.3 to $11 \mathrm{~cm}$ long, $0.28 \mathrm{~cm}$ in diameter, and yellowish brown in color.

The flower has five to six green sepals and five to six milky white petals. The arrangement of petals is separated at the base. The corolla diameter is large, $\approx 5.5 \mathrm{~cm}$ long. The flower has 32 to 35 upright stigmas and 56 to 60 yellowish brown anthers, which do not produce viable pollen as a result of the functional dioecism. The flowers occur in cymes from nodes 1 to 6 ; the majority has three flowers $(63 \%)$, two flowers $(15 \%)$, or a single flower $(21 \%)$, and a few cymes have four flowers, which cost more in labor for thinning flowers under orchard management. The fruit is cylindrical and slightly depressed at the stylar end and squared at the stalk end. The fruit surface is yellowish brown color with sparse short hairs. The fruit skin is thick with conspicuous lenticels. The transverse 
A

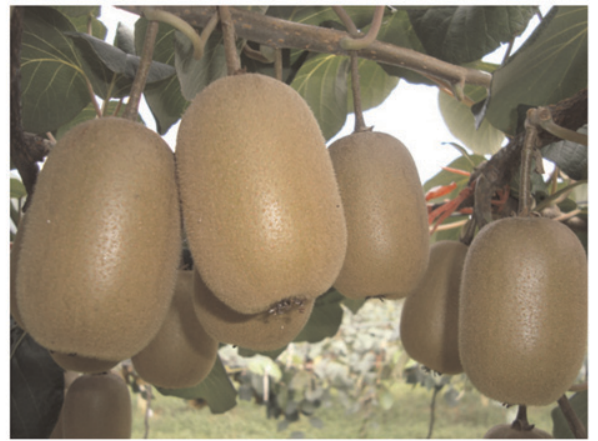

B

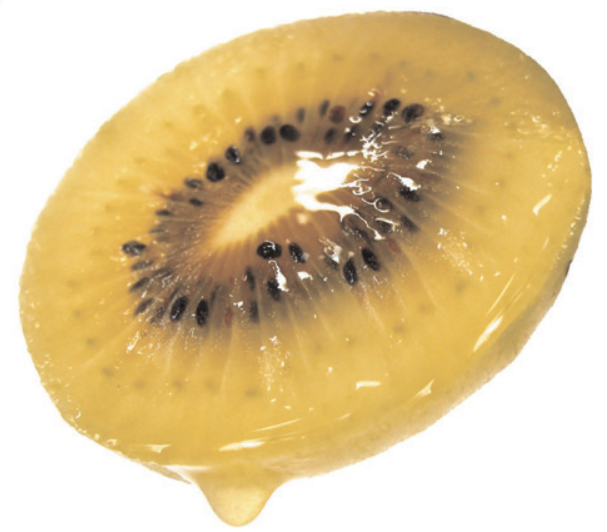

Fig. 1. Fruit of 'Jinyan': (A) fruiting on vine; (B) transverse section of 'Jinyan' fruit at eating ripe.

section of the fruit is circular with a small (diameter 0.64 to $0.43 \mathrm{~cm}$ ), soft, edible core. The fruit stalk is $4.31 \mathrm{~cm}$ long and $0.28 \mathrm{~cm}$ in diameter. The mature seed are orbicularovate and yellowish brown after air drying. The seed number per fruit is $\approx 450$ to 700 and the weight of 1000 seeds is $\approx 1.7 \mathrm{~g}$.

The fruit is large and uniform; average single fruit weight is $101 \mathrm{~g}$ with maximum $175 \mathrm{~g}$ under good orchard management. The flesh is green-yellow (flesh hue $\approx 109$ ) at harvest but changes to yellow (flesh hue $\approx 103.6$ ) and brilliant yellow (flesh hue $\approx 98$ ), similar to 'Jintao' (Huang et al., 2002) during postharvest storage. The fruit has a tender texture, juicy, sweet, and aromatic taste. When the fruit is at eating ripe (flesh firmness 0 to $1.5 \mathrm{~kg} \cdot \mathrm{cm}^{-2}$ ), the content of vitamin C, titratable acidity (citric acid equivalent), total sugars, and soluble solids was $104.7 \mathrm{mg} / 100$ g, $1.0 \%, 9.6 \%$, and $14.2 \%$ to $19.8 \%$, respectively. Total amino acid content was $0.94 \%$, of which glutamic acid was nearly $0.25 \%$, far more than commercial 'Hayward' fruit. 'Jinyan' fruit were also very rich in potassium $(2548.8$ $\mathrm{mg} \cdot \mathrm{kg}^{-1}$ ) and calcium (353.3 $\left.\mathrm{mg} \cdot \mathrm{kg}^{-1}\right)$, far more than 'Hayward' fruit, which would be a health benefit if the fruit is consumed regularly (Tables 1 and 2).

'Jinyan' has a long storage and shelf life. The flesh firmness of 'Jinyan' at harvest was high, 18.0 to $20.9 \mathrm{~kg} \cdot \mathrm{cm}^{-2}$. It needs $42 \mathrm{~d}$ from

Table 1. Main fruit characteristics of 'Jinyan' and other important commercial kiwifruit cultivars in China. ${ }^{\text {' }}$

\begin{tabular}{|c|c|c|c|c|c|c|c|}
\hline Characteristics & Jinyan & Hayward & Jintao & Hongyang & Jinkui & Miliang No.1 & Qinmei \\
\hline $\begin{array}{l}\text { Fruit surface hair } \\
\text { at harvest }\end{array}$ & Short, sparse & $\begin{array}{l}\text { Abundant } \\
\text { and stiff }\end{array}$ & Hairless & Hairless & $\begin{array}{l}\text { Abundant } \\
\text { and stiff }\end{array}$ & Long, fuzzy & $\begin{array}{l}\text { Abundant } \\
\text { and stiff }\end{array}$ \\
\hline $\begin{array}{l}\text { Fruit skin color } \\
\text { at harvest }\end{array}$ & Yellow-brown & Brown & Light brown & $\begin{array}{c}\text { Greenish } \\
\text { brown }\end{array}$ & Brown & Brown & Brown \\
\hline $\begin{array}{l}\text { Flesh color at } \\
\text { eating ripe }\end{array}$ & $\begin{array}{l}\text { Brilliant } \\
\text { yellow }\end{array}$ & Green & $\begin{array}{l}\text { Orange } \\
\text { yellow }\end{array}$ & $\begin{array}{l}\text { Yellowish } \\
\text { green }\end{array}$ & Green & $\begin{array}{l}\text { Yellowish } \\
\text { green }\end{array}$ & Green \\
\hline $\begin{array}{l}\text { Flesh taste at eating } \\
\text { ripe }\end{array}$ & Sweet & Sour and sweet & Sweet & Sweet & Sweet & $\begin{array}{c}\text { Sour and } \\
\text { sweet }\end{array}$ & $\begin{array}{c}\text { Sour and } \\
\text { sweet }\end{array}$ \\
\hline $\begin{array}{l}\text { Flesh aroma at } \\
\text { eating ripe }\end{array}$ & Aromatic & Aromatic & Aromatic & Light & Aromatic & Aromatic & Aromatic \\
\hline $\begin{array}{l}\text { Vitamin C at eating } \\
\text { ripe }^{\mathrm{v}}(\mathrm{mg} / 100 \mathrm{~g})\end{array}$ & $104.7 \pm 8.90$ & $64.4 \pm 7.35$ & $177.6 \pm 17.70$ & $83.1 .0 \pm 8.70$ & $146.7 \pm 7.31$ & $135.0 \pm 4.64$ & $118.8 \pm 7.65$ \\
\hline $\begin{array}{l}\text { Dry matter at eating } \\
\operatorname{ripe}^{\mathrm{r}}(\%)\end{array}$ & $15.8 \pm 0.43$ & $15.5 \pm 0.17$ & $17.2 \pm 0.28$ & $16.9 \pm 1.46$ & $20.3 \pm 0.48$ & $13.8 \pm 0.70$ & $11.8 \pm 0.42$ \\
\hline Firmness at harvest ${ }^{\mathrm{q}}$ & $19.6 \pm 0.92$ & $19.1 \pm 0.47$ & $11.4 \pm 0.62$ & $11.2 \pm 1.04$ & $18.4 \pm 0.51$ & $12.2 \pm 0.13$ & $12.0 \pm 0.56$ \\
\hline
\end{tabular}

${ }^{\mathrm{z}}$ Fruit samples were harvested from kiwifruit cultivar orchard at Wuhan Botanical Garden in 2009-2010.

${ }^{\mathrm{y}}$ Fruit weights was measured using METTLEER TOLEDO-PB303-8 (Switzerland) (the range is 0.02 to $320 \mathrm{~g}$, precisions $0.001 \mathrm{~g}$ ).

${ }^{\mathrm{x}}$ The position of color measurement is out pericarp.

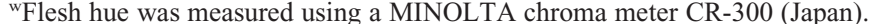

vVitamin C was analyzed using the standard 2,4-dinitrophenylhydrazine method (GB/T 5009.86-2003).

"Soluble solids content was measured using Atago palette digital refractometer (Brix 0\% to 45\%, Japan).

'Total sugar content was analyzed using the standard method of GB/T 5009.7-2008.

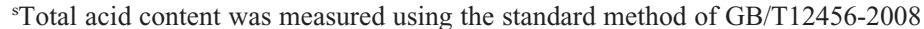

${ }^{\mathrm{r}}$ Dry matter content was measured using the standard method of GB/T 8858-1988.

${ }^{9}$ Firmness was measured using a digital Sclerometer [GY-4, China; the measurement range of this digital Sclerometer is 0.4 to $30 \mathrm{~kg} \cdot \mathrm{cm}^{-2}\left(\times 10^{5} \mathrm{~Pa}\right) \mathrm{using} 7.9-\mathrm{mm}$ diameter Effegi probe)]. 
harvest to eating ripe at room temperature (daily mean temperature 15 to $20{ }^{\circ} \mathrm{C}$ ). The edible period at room temperature could reach 10 to $15 \mathrm{~d}$, whereas the best edible period could last for 4 to 5 months in a refrigerator $\left(3{ }^{\circ} \mathrm{C}\right)$. The storage trails showed that when 'Jinyan' was stored in cold $\left(0 \pm 0.5^{\circ} \mathrm{C}\right.$, relative humidity $85 \%$ to $95 \%$ ) and controlled atmosphere (CA: $2 \%$ to $3 \% \mathrm{O}_{2}, 3 \%$ to $5 \% \mathrm{CO}_{2}$ ) storage for 8 months, or at room temperature for 3 months, $\approx 90 \%$ of 'Jinyan' kiwifruit remained healthy at the end of 8 months CA storage or 3 months storage in ambient (Table 3).

In the Wuhan region, Hubei Province (lat. $30^{\circ} 37^{\prime} \mathrm{N}$, long. $114^{\circ} 8^{\prime} \mathrm{E}$; having a typical continental climate with cold winters monthly averaging between 7.7 and $-1.1^{\circ} \mathrm{C}$ in January and hot summers averaging between 33.8 and $25.6^{\circ} \mathrm{C}$ in July), sap-flow in 'Jinyan' starts in late February, budbreak occurs in early March, and shoot growth begins in late March or early April. Flowering begins $\approx 26$ Apr. and ends by $\approx 7$ May. Fruit size increases rapidly during the period from early May to late June. Fruit can be harvested in late October or early November when soluble solids content reaches $6.5 \%$ or higher. 'Jinyan' therefore requires a growing season of $\approx 200 \mathrm{~d}$ and is normally harvested 40 to 45 d later than 'Hort16A' (early or midSeptember) but similar to the 'Hayward' harvest period (late October) (Table 4).

\section{Performance}

'Jinyan' bears fruit mainly on long fruiting shoots and short shoots. Long fruiting shoots account for $65 \%$, short fruiting shoots $30 \%$, and medium shoots only $5 \%$ among all fruiting shoots. Generally, 'Jinyan' does not produce water shoots. The fruiting shoots originate mainly from the first to sixth nodes of which $88 \%$ to $95 \%$ bears fruit. Each fruiting shoots can bear six to 12 fruits. In commercial production, it is necessary to remove lateral small flowers and five to seven fruits per fruiting shoot remaining for large fruit size. Compared with 'Hayward', 'Jinyan' is higher in terms of bubreak rate, fruiting shoot rate, and

Table 2. Amino acid and mineral nutrient contents of 'Jinyan', 'Hayward', and 'Hongyang' kiwifruit.

\begin{tabular}{|c|c|c|c|c|c|}
\hline \multicolumn{2}{|c|}{ Cultivar } & Jinyan & Hayward & Hongyang & Measure method \\
\hline \multirow[t]{3}{*}{ Mineral elements } & Nitrogen $(\%)$ & $0.19 \pm 0.015$ & $0.13 \pm 0.015$ & $0.17 \pm 0.015$ & GB/T 5009,5-2003 \\
\hline & Potassium $\left(\mathrm{mg} \cdot \mathrm{kg}^{-1}\right)$ & $2548.75 \pm 287.01$ & $1764.25 \pm 238.572$ & $1588.75 \pm 260.282$ & \\
\hline & Calcium $\left(\mathrm{mg} \cdot \mathrm{kg}^{-1}\right)$ & $353.25 \pm 34.944$ & $275.75 \pm 80.451$ & $178.75 \pm 20.310$ & \\
\hline Total amino acids & & $0.94 \pm 0.097$ & $0.71 \pm 0.176$ & $0.78 \pm 0.066$ & GB/T 5009, \\
\hline Glutamic acids $(\%$ & & $0.25 \pm 0.020$ & $0.10 \pm 0.040$ & $0.20 \pm 0.027$ & 124-2003 \\
\hline Aspartic acids (\%) & & $0.11 \pm 0.021$ & $0.093 \pm 0.027$ & $0.10 \pm 0.020$ & \\
\hline
\end{tabular}

${ }^{\mathrm{z}}$ Fruits were sampled from the commercial orchards at Pujiang county, Sichuan Province, and analyzed at eating ripe.

Table 3. Comparison of storage at $0{ }^{\circ} \mathrm{C}$ with ethylene absorbent of 'Jinyan' and other main kiwifruit cultivars in China.,

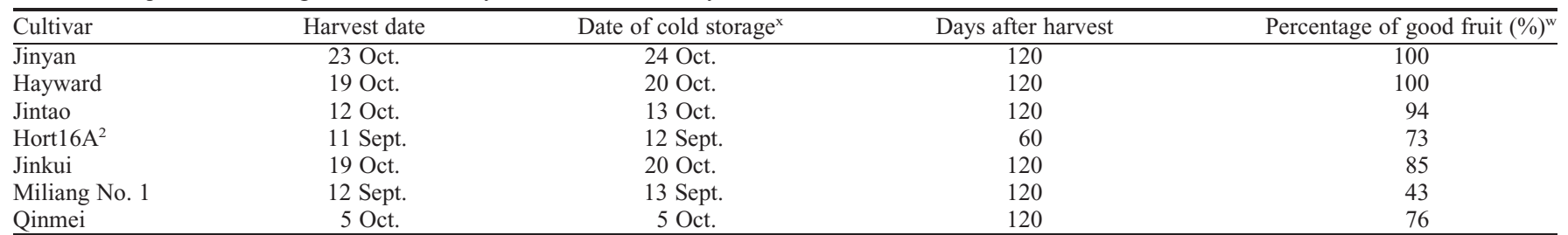

${ }^{2}$ Data were collected during 2008-2010. 'Jinyan', 'Jintao', and 'Hort16A' harvested at an average soluble solids content greater than 7\%; 'Hayward', 'Jinkui', 'Miliang No. 1', and 'Qinmei' harvested at an average soluble solids content greater than $6.5 \%$.

${ }^{\text {y} F r u i t ~ s a m p l e s ~ o f ~ ' J i n y a n ' ~ a n d ~ o t h e r ~ m a i n ~ k i w i f r u i t ~ c u l t i v a r s ~(e x c e p t ~ ' H o r t 16 A ') ~ p r o d u c e d ~ i n ~ W u h a n ~ B o t a n i c a l ~ g a r d e n ~ H u b e i ~ P r o v i n c e ~ i n ~ C h i n a . ~ ' H o r t 16 A ' ~ i s ~ n o t ~}$ commercially grown in China; the data were collected from a 1-acre trial block of Zhongxin Agricultural Science \& Technology Co., Ltd., Sichuan Province. ${ }^{\mathrm{x}}$ Fruit were cured for $1 \mathrm{~d}$ at ambient temperature after harvest before cool storage in ethylene free air at $0{ }^{\circ} \mathrm{C}$ started.

${ }^{w}$ Percentage of healthy fruit (fruit free from disorders such as rots, pitting and soft patches) was assessed after $3 \mathrm{~d}$ of simulated shelf life at $10{ }^{\circ} \mathrm{C}$ after cool storage.

Table 4. Phenology of 'Jinyan' in comparison with other cultivars.

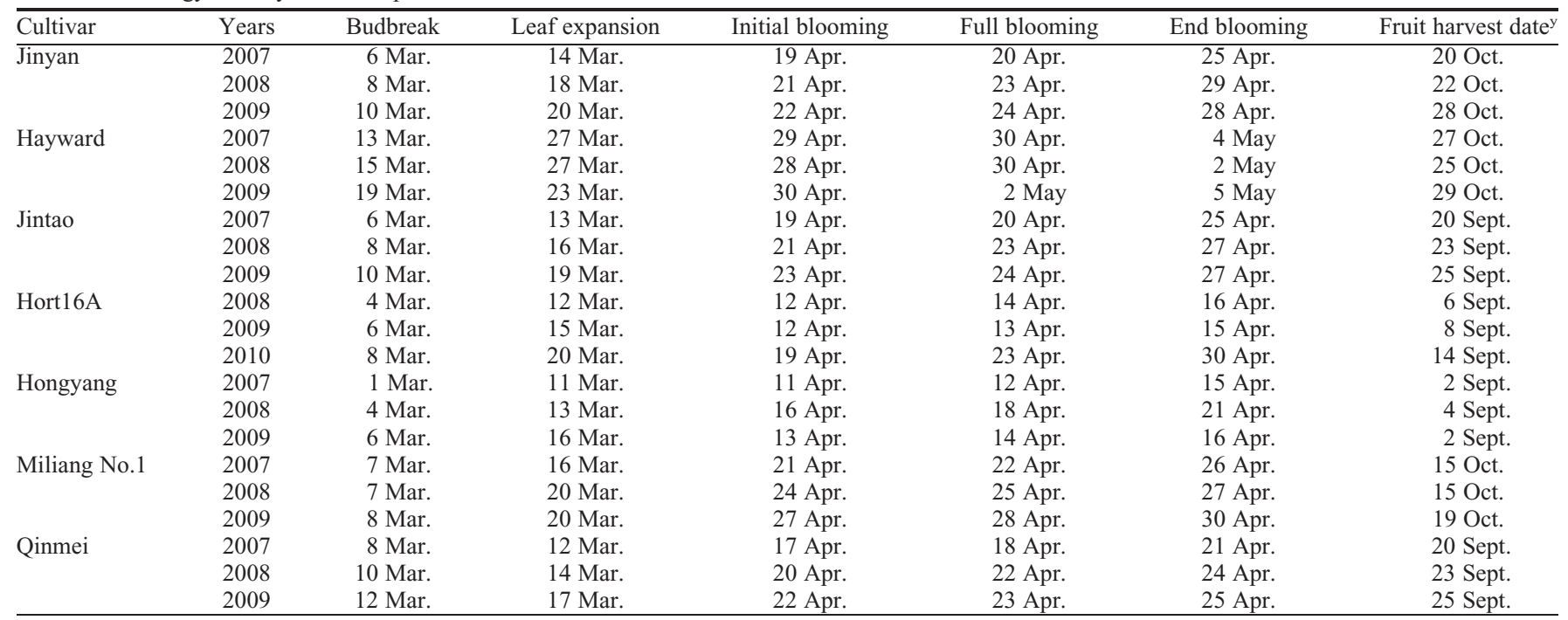

The data were collected from kiwifruit breeding orchard of the Wuhan Botanical Garden, Wuhan, Hubei, China.

' 'Hayward', 'Miliang No. 1', and 'Qinmei' harvested at an average soluble solids content greater than 6.5\% and 'Jinyan', 'Hort16A', 'Jintao', and 'Hongyang' harvested at an average soluble solids content greater than $7 \%$. 
Table 5. Comparison of fruiting habits of 'Jinyan'and other main kiwifruit cultivars (2007-2009).

\begin{tabular}{|c|c|c|c|c|c|c|}
\hline & \multirow{7}{*}{$\begin{array}{c}\text { Wuhan Botan } \\
\begin{array}{c}\text { Budbreak } \\
\text { rate }(\%)\end{array} \\
50.0 \\
31.0 \\
34.0 \\
- \\
34.7 \\
38.3 \\
24.0 \\
\end{array}$} & \multirow{3}{*}{$\begin{array}{c}\text { Hubei Province } \\
\begin{array}{c}\text { Fruiting shoot } \\
\text { rate }(\%)\end{array} \\
90.0\end{array}$} & \multicolumn{2}{|c|}{ Pujiang county, Sichuan Province } & \multirow[b]{2}{*}{$\begin{array}{l}\text { Avg number of fruit } \\
\text { set per shoot }\end{array}$} & \multirow[b]{2}{*}{$\begin{array}{l}\text { Node location } \\
\text { for flowers }\end{array}$} \\
\hline Cultivar & & & $\begin{array}{c}\text { Budbreak } \\
\text { rate }(\%)\end{array}$ & $\begin{array}{l}\text { Fruiting shoot } \\
\text { rate }(\%)\end{array}$ & & \\
\hline Jinyan & & & 67.1 & 100.0 & 8.0 & $1-6$ \\
\hline Hayward & & 10.0 & 56.7 & 67.8 & 3.2 & $2-5$ \\
\hline Hort16A & & - & 91.6 & 97.5 & 5.5 & $1-6$ \\
\hline Hongyang & & 100.0 & 92.0 & 100.0 & 5.0 & $1-6$ \\
\hline Jinkui & & 54.8 & 69.2 & 77.8 & 3.9 & $1-5$ \\
\hline
\end{tabular}

the number of fruit set per shoot (Table 5). All this indicates that 'Jinyan' is a good cultivar with excellent high-yield characteristics. 'Jinyan' bears fruit precociously, i.e., it can produce $18 \mathrm{~kg}$ of fruit per vine in the second year after top-grafting on 3-year root stock and 32 $\mathrm{kg}$ of fruit in the third year (pergola system with a planting density of $4 \mathrm{~m} \times 3 \mathrm{~m})$. Mature 'Jinyan' kiwifruit vines produced a maximum yield of $100 \mathrm{~kg} / \mathrm{vine}$ or $45 \mathrm{t} \cdot \mathrm{ha}^{-1}$ without showing a market biennial bearing. Since 1996, field trials of 'Jinyan' have been established with grafted plants at different altitudes in Hubei, Shandong, Jiangxi, Sichuan, and Shaanxi Provinces. The results show that 'Jinyan' is adaptable and can tolerate both high summer temperatures and cold winter temperatures; vines grow well and set fruit normally at both high and low altitudes in different provinces. Although 'Jinyan' is generally tolerant to common kiwifruit disease, it is easily infected by bacterial flower rot if the weather is cold and wet during flowering. It is necessary to thin lateral flowers and to spray pesticides. It is very important to maintain orchard hygiene during winter. The selected pollenizer for 'Jinyan' is 'Moshan No. 4' with blooming time from 24 Apr. to 8 May.

\section{Availability}

Propagation rights of 'Jinyan' were licensed domestically in China when 'Jinyan' was approved by the Hubei Provincial Forest Cultivar Appraisal Committee in 2006. The China New Agricultural Science \& Technology Co. Ltd. (Sichuan) has the right to cultivate 'Jinyan' in China.

\section{Literature Cited}

Huang, H.W. 2009. History of 100 years of domestication and improvement of kiwifruit and gene discovery from genetic introgressed populations in the wild. Chinese Bull. Bot. 44:127142 [in Chinese and English abstract].
Huang, H.W., S.M. Wang, R.H. Huang, Z.W. Jiang, and Z.H. Zhang. 2002. 'Jintao', a novel, hairless, yellow-fleshed kiwifruit. HortScience 37:1135-1136.

Wang, S.M., H.W. Huang, Z.H. Zhang, Z.W. Jiang, S.R. Zhang, and H.Q. Huang. 2000. Studies on Actinidia breeding by species hybridization between A. chinensis and A. eriantha and their hybrids' progenies, p. 123-127. In: Huang, H.-W. (ed.). Advances in Actinidia Research [in Chinese and English abstract]. Science Press, Beijing, China.

Wang, S.M., R.H. Huang, X.W. Wu, and N. Kang. 1994. Studies on Actinidia breeding by species hybridization. J. Fruit Sci. 11:23-26 [in Chinese and English abstract].

Wang, S.M., X.W. Wu, R.H. Huang, Z.T. Xiong, and S.Q. Ke. 1989. Preliminary report on fluctuation of interspecific crosses of Chinese gooseberry. J. Wuhan Bot. Res. 7:399-402 [in Chinese and English abstract].

White, A. and R.A. Beatson. 1993. Evaluation of a new kiwifruit hybrid. In: Proc. Australasian Postharvest Conf., Gatton College, Queensland, Australia, 20-24 Sept. 1993. p. 161-163. 